\title{
Laxative Activity of the Hot-Water Extract Mixture of Hovenia dulcis Thunb. and Phyllostachys pubescens Mazel in Chronic Constipation Model SD Rats
}

\author{
Kyo-Nyeo Oh', Yujin Kim', Eun Jin Choi', Hyunmi Lee', Ji Ae Hong', Miri Kim', Dool-Ri Oh', \\ Myung-A Jung' ', Ro-Dong Park², Seong-il Kim², Ju-seon Yong ${ }^{2}$, Hui-Seop Lee ${ }^{2}$, SangOh Ban', \\ and Chul-yung Choi ${ }^{1 *}$ \\ 'Jeonnam Bioindustry Foundation, Jeonnam Institute of Natural Resources Research, Jangheung-gun 59338, \\ Republic of Korea \\ ${ }^{2}$ Agroceuticals Lab, Haenam Natural Farming Association Corporation, Gwangju 61111, Republic of Korea
}

This study examined the laxative effects of hot-water extracts of Hovenia dulcis Thunb. (HD), Phyllostachys pubescens Mazel (PM), and a 2:8 mixture of both (HP) in two chronic constipation models. For the loperamide-induced constipation model, animals were divided into an untreated group, negative control group (loperamide $4 \mathrm{mg} / \mathrm{kg}$ ), positive control group (bisacodyl $4 \mathrm{mg} / \mathrm{kg}$ ) group, and six treatment groups (HP 100 or 400, HD 50 or 100, and PM 100 or $400 \mathrm{mg} / \mathrm{kg}$ ). For the lowfiber diet-induced constipation model, animals were divided into an untreated group (normal diet), negative control group (low-fiber diet), positive control group (Agio granule, $620 \mathrm{mg} / \mathrm{kg}$ ), and the same treatment groups. Fecal number, weight, fecal water content, and intestinal transit ratio were higher in the groups treated with HP, HD, and PM than in the groups treated with loperamide or lowfiber diet. Thickness of colon mucosa and muscle layers were increased in the treated groups. Colon tension increased in the HP groups, and $\left[\mathrm{Ca}^{2+}\right] \mathrm{i}$ measurements using fura-2 as an indicator showed that HP inhibits ATP-mediated $\mathrm{Ca}^{2+}$ influx in IEC-18 cells. These results showed that the HP mixture has laxative activity by increased mucin secretion and inducing contractile activity and relaxation. It may be a useful therapeutic strategy for ameliorating in chronic constipation.

Keywords: Constipation, Hovenia dulcis Thunb., laxative activity, $\mathrm{Ca}^{2+}$ influx, Phyllostachys pubescens Mazel

Received: November 22, 2019 Accepted: February 18, 2020

First published online: February 21, 2020

* Corresponding author Phone: +82-61-860-2620 Fax: +82-61-864-7105 E-mail: blockstar@hanmail

pISSN 1017-7825 eISSN 1738-8872

Copyright(C) 2020 by The Korean Society for Microbiology and Biotechnology

\section{Introduction}

Gastrointestinal dysfunction is characterized by various symptoms including abdominal inflation, constipation, diarrhea, discomfort, anxiety, or depression [1]. Chronic constipation is one of the most common gastrointestinal issues, affecting about $15 \%$ of all adults and 30\% of those over the age of 60 [2]. Constipation is characterized by infrequent or difficult evacuation of feces, defined as fewer than three bowel movements per week $[3,4]$. Currently, various laxatives are used to decrease symptoms and most solutions for constipation focus on modulating the motility of the gastrointestinal tract [5]. The laxatives for constipation treatment are bulkforming agents (i.e. bran, seaweed, methylcellulose derivatives, and calcium polycarbophil), osmotic agents (i.e. magnesium salts and sodium phosphate), hyperosmotic agents (i.e. lactulose, sorbitol, lactitol, polyethylene glycol, stimulant agents (i.e. senna, aloe, and bisacodyl), surfactants (i.e. docusate, castor oil and dehydrocholic acid), and other laxatives (i.e. 5-hydroxytryptamine (5-HT) 4 agonists, Cl-channel activators, and guanylate cyclase-C agonists) [6]. Each agent has one or more mechanisms for constipation treatment. However, some of these drugs are reported to have severe side effects (cisapride as promotility agent: cardiac arrhythmias [7, 8]; tegaserod as selective $5-\mathrm{HT}_{4}$ receptor agonist [9]: coronary artery contraction, coronary spasm, and myocardial infarction). Moreover, long-term treatment with stimulant laxatives leads to steatorrhea, pancreatitis, renal failure, rhabdomyolysis, and melanosis coli [10-13.]. Many studies, including clinical trials, have been carried out to develop new safer therapies for chronic constipation [14].

Hovenia dulcis Thunb., of the Rhamnaceae family, is a hardy tree found in Korea, Japan, Eastern China, and other parts of Asia [15]. The roots, seed, fruit, leaves, and branches of Hovenia dulcis Thunb. have been used as a traditional herbal medicine. It is well-known for treating liver diseases, alcohol-induced hangover, cancer, steatosis, inflammation, acute hyperlipidemia, and atopic dermatitis-like skin lesions [16-21]. Although many studies have revealed the medical efficacy of Hovenia dulcis Thunb., there have been very few studies focusing on 
alleviating constipation.

Bamboo, of which there are approximately 75 species, is a common plant in Asia. There are 200 varieties of Phyllostachys including Phyllostachys pubescens Mazel (Moso bamboo), Phyllostachys nigra, Sasa borealis, Phyllostachys bambusoides, and Phyllostachys nigra var. henonis (Mitford) Stapf. ex Rendle [22]. Bamboo extracts have diverse physiological functions such as antioxidant, free radical-scavenging, antiobesity, anticancer, neuroprotective, immune regulating, and antifungal effects [22-26]. Bambusae caulis, a medicinal herb derived from the inner branch of Phyllostachys nigra var. henonis (Mitford) Stapf. ex Rendle, has been used to treat inflammation, fever, diarrhea, and intestinal inflammation [27-29].

As a preliminary experiment, constipation relief experiments were performed with various ratios $(2: 8,5: 5$, and 8:2) of Hovenia dulcis Thunb. (HD) branch and Phyllostachys pubescens Mazel (PM) hot water extracts. The HD and PM 2:8 mixture (HP 2:8 mixture) was determined to be the most effective for improving constipation, and the mechanism of constipation alleviation was investigated.

In this study, we evaluated the laxative effect of the extract of Hovenia dulcis Thunb., Phyllostachys pubescens Mazel, and a mixture of the two. We found out that the extract of mixture of the two (HP 2:8) showed a laxative effect when treating loperamide-treated constipation model rats and low-fiber diet-treated constipation model rats. The HP 2:8 mixture's mechanism of alleviating constipation of has been elucidated for further application.

\section{Materials and Methods \\ Chemicals}

Loperamide hydrochloride, gum arabic, charcoal, hematoxylin \& eosin, and the voltage-dependent $\mathrm{Ca}^{2+}$ channel (VDCC) blocker nifedipine were purchased from Sigma Chemical Co. (USA). Dulcolax S was purchased from Sanofi-Aventis Korea Co. (Korea). Agio granule was purchased from BUKWANG PHARM.CO.,LTD (Korea). IEC-18 (ATCC CRL-1589), an epithelial cell line derived from the colon of rat intestines, was purchased from American Type Culture Collection (USA). Dulbecco's Modified Eagle Medium (DMEM) and Fetal Bovine Serum (FBS) were purchased from Invitrogen Inc. (USA).

\section{Plant Material}

The branches of Hovenia dulcis Thunb. (HD) were purchased from Jangheung Heotgae Farming Association Corporation, Jangheung-Gun (Jeollanam-Do) and the leaves of Phyllostachys pubescens Mazel (PM) from Baekok Industry, Gyeongsan (Gyeongsangbuk-Do) in South Korea. Air-dried branches and leaves were chopped into small pieces. The chopped branches $(20 \mathrm{~kg})$ of HD were extracted twice with $200 \mathrm{~L}$ of water at $100 \pm 5^{\circ} \mathrm{C}$ for $3 \mathrm{~h}$ and combined together. The combined extract was concentrated at $85^{\circ} \mathrm{C}$ for $5 \mathrm{~h}$, lyophilized, pulverized and passed through a 60 mesh sieve. The final yield of HD was $3.7 \%$. The chopped leaves $(20 \mathrm{~kg})$ of PM were extracted 2 times with $400 \mathrm{~L}$ of water at $100 \pm 5^{\circ} \mathrm{C}$ for $3 \mathrm{~h}$, and concentrated, lyophilized, and pulverized under the same process as for HD. The yield of PM was $12.9 \%$. Hovenia dulcis Thunb. (HD) and Phyllostachys pubescens Mazel (PM) mixed (2:8) hot-water extract (HP 2:8 mixture) was prepared with $200 \mathrm{~g}$ of HD and $800 \mathrm{~g}$ of PM. The same samples as those used in the clinical trial study which is approved by Institutional Review Board (IRB), were used for present study. IRB approval: Institutional Review Board of Wonkwang University, Gwangju medical center (2018.05.02). Clinical trials registration number: WCTC-HD-PM Ver 1.0.

\section{Animals}

Male Sprague-Dawley rats (6 weeks old) were purchased from Samtako Bio Korea (Korea). Animals were maintained at a constant room temperature of $22 \pm 2^{\circ} \mathrm{C}$ with a humidity level of $50 \pm 5 \%$ and with free access to water and food under a 12:12 h light : dark cycle (lights on at 8:00 am). The animals were acclimatized for 7 days before beginning the experiments. All experimental procedures were conducted in accordance with the relevant guidelines for the care of experimental animals and were approved by the Institutional Animal Care and Use Committee (IACUC) at the Jeonnam Institute of Natural Resources Research (approval number JINR-1807 and JINR-1823). Every experimental group consisted of 7 animals and each rat was used only once. We randomly assigned seven rats to each of six experimental groups (100 and $400 \mathrm{mg} / \mathrm{kg} \mathrm{HP} 2: 8$ mixture, 50 and $100 \mathrm{mg} / \mathrm{kg} \mathrm{HD}$ and 100 and $400 \mathrm{mg} / \mathrm{kg} \mathrm{PM}$ ) and also to a normal control group, loperamide or low-fiber diet group and positive group (bisacodyl, Agio granule). Agio granule is the bulk-forming agent contained the psyllium husk. The loperamide was given for all groups except normal control group. This also applied the low-fiber diet-induced constipation model. Administration of experimental samples for the two constipation rat models began after 1 week of adaptation and observation.

\section{Experimental design for constipation}

For the loperamide-induced constipation model, constipation was induced in the animals through oral administration of $4 \mathrm{mg} / \mathrm{kg}$ loperamide hydrochloride daily for 7 days and $1 \mathrm{~h}$ prior to experiment sample administration, as described previously $[30,31]$. The normal control group was administered saline. The HP 2:8 mixture (100 and $400 \mathrm{mg} / \mathrm{kg}$ ), HD (50 and $100 \mathrm{mg} / \mathrm{kg}$ ), and PM (100 and $400 \mathrm{mg} / \mathrm{kg}$ ) were dissolved in distilled water (DW) and administered orally $1 \mathrm{~h}$ after loperamide administration for 7 days. The positive control (bisacodyl $4 \mathrm{mg} / \mathrm{kg}$ ) was dissolved in DW and administered orally as a treatment reference [32]. For the low-fiber diet-induced constipation animal model, the rats were fed a normal or low-fiber diet. The low-fiber diet containing corn starch (41.5\%), corn oil (6.0\%), dextrin (10.0\%), mineral mixture (7.0\%), vitamin mixture (1.0\%), sucrose (10.0\%), and milk casein (24.5\%) was purchased from Saeronbio Inc. (Korea) (Table 1). After 21 days of administration of the diet to induce constipation, experimental samples were orally administered for 14 days 
Table 1. Composition of normal diet and low-fiber diet.

\begin{tabular}{|c|c|c|}
\hline \multirow{2}{*}{ Ingredients } & \multicolumn{2}{|c|}{ Contents (\%) } \\
\hline & Normal diet & Low-fiber diet \\
\hline Moisture & 9.2 & 9 \\
\hline Fiber & 4.7 & 0.1 \\
\hline Protein & 20 & 21.9 \\
\hline Fat & 9.9 & 6.1 \\
\hline Ash & 6 & 5.9 \\
\hline Nitrogen-free extract & 50.2 & 57 \\
\hline
\end{tabular}

(Fig. 1). Food intake, water intake, body weight, and fecal water content were measured, and tissue samples were taken from each rat.

\section{Analysis of Body Weight, Food Intake, and Water Intake}

For loperamide-induced constipation, the body weight was measured every two days before administration of loperamide. Food intake and water intake were measured every day for all of the animals before administration of loperamide. For low-fiber diet-induced constipation, the body weight was measured every 7 days, and food intake and water intake were measured daily at 9:00 am.

\section{Evaluation of Constipation (Fecal Parameters)}

Fecal parameters were measured every day for all of the animals before administration. The fecals were collected and dried at $70^{\circ} \mathrm{C}$ for $24 \mathrm{~h}$, and the total water content was calculated as the difference between the wet and dry weights of fecals. Fecal water content $(\%)=[($ fecal wet weight - fecal dry weight $) /$ fecal wet weight $] \times 100$.

\section{Gastrointestinal Charcoal Transit Ratio and Tissue Sampling}

Charcoal excretion containing gum arabic was performed on the last day of the experiment. Measurement of the gastrointestinal propulsion of a charcoal meal was determined according to the modified method by Choi et al. [30]. Briefly, the animals were fasted for $18 \mathrm{~h}$ prior to the experiment, but were permitted water (ad libitum). After $18 \mathrm{~h}$, the animals were orally administrated $1 \mathrm{ml}$ gum arabic with charcoal $(5 \% / 10 \%$, w/w) via the same route immediately after sample administration. Gum arabic $(5 \% \mathrm{w} / \mathrm{w})$ was orally administrated as a vehicle. At $30 \mathrm{~min}$ after the charcoal meal administration, the animals were anaesthetized. Then, the total intestine length and charcoal meal transit distance were measured and the fecals in the distal colon were counted. The intestinal charcoal transit ratio was expressed as a percentage of travelled distance: Charcoal transit ratio $(\%)=[($ total intestine length - transited charcoal meat distance)/total intestine length] $\times 100$. The colonic segment was isolated with ligatures and fixed with $10 \%$ formaldehyde at the time of intestinal charcoal transit ratio measurement.

\section{Histological Analysis}

The fixed tissue segments were embedded in paraffin and serially cut into cross sections $5 \mu \mathrm{m}$ thick. The sections were stained with H\&E. Five tissue segments per group were prepared and the histological profiles interpreted. The colonic mucosal thickness, villus length, crypt thickness and muscle thickness were measured by Leica Application Suite (Leica Microsystem, Switzerland) using a light microscope.

\section{Preparation of Colon}

Male SD rats (200 250 g) were fasted for $18 \mathrm{~h}$ and sacrificed under anesthesia. An approximately $7 \mathrm{~cm}$ length of the colon was removed and placed in Krebs solution containing $\mathrm{NaCl} 111, \mathrm{KCl} 5.9, \mathrm{MgCl}_{2} 1.2, \mathrm{CaCl}_{2} 2.0, \mathrm{KH}_{2} \mathrm{PO}_{4}$ $1.2, \mathrm{NaHCO}_{3} 25$, and glucose $11.5 \mathrm{mM}$. The Krebs solution was maintained at a $\mathrm{pH}$ of 7.4 and continuously aerated with carbogen $\left(95 \% \mathrm{O}_{2} / 5 \% \mathrm{CO}_{2}\right)$. Subsequently, the colon was flushed with buffer solution, cleaned of mesenteric tissues and cut into segments $0.5 \mathrm{~cm}$ in length. The colon segments were clamped in $10 \mathrm{ml}$ organ baths containing Krebs solution maintained at $37^{\circ} \mathrm{C}$ and aerated with carbogen. Contractions of the longitudinal muscle of isolated colon were measured with force transducers connected to a physiograph recorder (Labchart; AD Instruments, Australia) and a Labchart data-acquisition system. A basal tension of $1 \mathrm{~g}$ was applied and allowed to relax, and then repeated tension was applied until the basal tone remained steady at about $0.6 \mathrm{~g}$ [33].

\section{Measurement of Contractile Activity}

The colon segments were allowed to equilibrate for a period of $1 \mathrm{~h}$ and the Krebs buffer was replaced every 15 min. After $1 \mathrm{~h}$ of equilibration, HP 2:8 mixture $(0.5,1,2 \mathrm{mg} / \mathrm{ml})$ was dissolved in Krebs buffer and tested on each

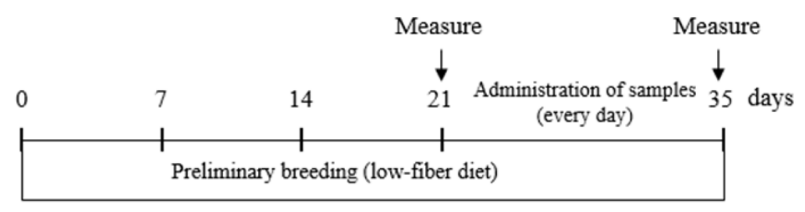

Fig. 1. The schedule of examination performed in this study. 
preparation to ensure that a stable and acceptable sensitivity had been reached. The spontaneous contractility of isolated rat colon was measured in the form of average contractile force (in grams over baseline) in a 30-min period. The change in spontaneous contraction (amplitude) was calculated as the average for $1 \mathrm{~min}$, and the frequency of spontaneous contraction was measured over 5 min [34].

\section{Cell Culture}

The IEC-18 rat ileum cell line was cultured in DMEM supplemented with 10\% FBS, $100 \mathrm{U} / \mathrm{ml}$ penicillin, and $100 \mu \mathrm{g} / \mathrm{ml}$ streptomycin at $37^{\circ} \mathrm{C}$ in a humidified atmosphere containing $5 \% \mathrm{CO}_{2}$.

\section{Intracellular Calcium Imaging}

The acetoxymethyl-ester form of fura-2 (fura-2/AM) was used as the fluorescent $\mathrm{Ca}^{2+}$ indicator. According to the modified method by Yang Z et al. [35], Cells were incubated for $60 \mathrm{~min}$ at room temperature with $5 \mu \mathrm{M}$ fura-2/ AM and $0.001 \%$ Pluronic F-127 in normal physiological saline solution (NPSS) composed of (in mM): $137 \mathrm{mM}$ $\mathrm{NaCl}, 5 \mathrm{mM} \mathrm{KCl}, 1 \mathrm{mM} \mathrm{MgCl}, 2.5 \mathrm{mM} \mathrm{CaCl}_{2}, 10 \mathrm{mM}$ HEPES, and $11 \mathrm{mM}$ glucose. The IEC-18 cells were stabilized in NPSS and $\mathrm{Ca}^{2+}$-free physiological saline solution (PSS : $137 \mathrm{mM} \mathrm{NaCl}, 5 \mathrm{mM} \mathrm{KCl}, 1 \mathrm{mM} \mathrm{MgCl}, 2$ $\mathrm{mM}$ EDTA, $10 \mathrm{mM}$ HEPES, $11 \mathrm{mM}$ glucose) was treated for $100 \mathrm{~s}$ in order to NPSS treated for $300 \mathrm{~s}$. The PSS + HP $2: 8$ mixture $(50,100,200 \mu \mathrm{g} / \mathrm{ml})$ was treated for $100 \mathrm{~s}$ and the NPSS + HP 2:8 mixture $(50,100,200 \mu \mathrm{g} / \mathrm{ml})$ was treated for $300 \mathrm{~s}$. After that, the NPSS + HP 2:8 mixture $(50,100,200 \mu \mathrm{g} / \mathrm{ml})+$ ATP $(100 \mu \mathrm{M})$ were treated for 300s. Cells were illuminated using a Lambda XL and excitation wavelengths ( 340 and $380 \mathrm{~nm}$ ) were selected. Data were acquired every 2 s. All imaging data were collected and analyzed using MetaMorph software.

\section{Statistical Analysis}

All data were expressed as the mean \pm standard error of the mean (SEM). The data were statistically evaluated using Student's $t$-tests or one-way analyses of variance (ANOVA) using GraphPad Prism (GraphPad Inc., USA) software program. The differences between the groups were assessed by Dunnett's multiple range test. The differences were considered significant at $p<0.05$.

\section{Results and Discussion}

\section{Effects on Fecal Parameters in Loperamide-Induced Constipation}

The fecal weight, number, and water content were assessed to determine the effects of HP 2:8 mixture on loperamide-induced constipation. Fecal weights were increased in HP mixed extract groups (100 and $400 \mathrm{mg} / \mathrm{kg}$ )

A

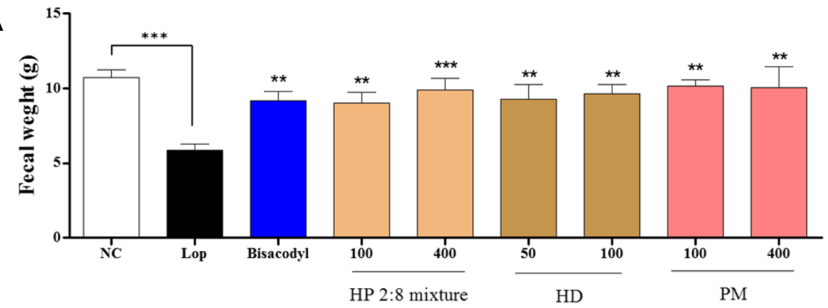

B
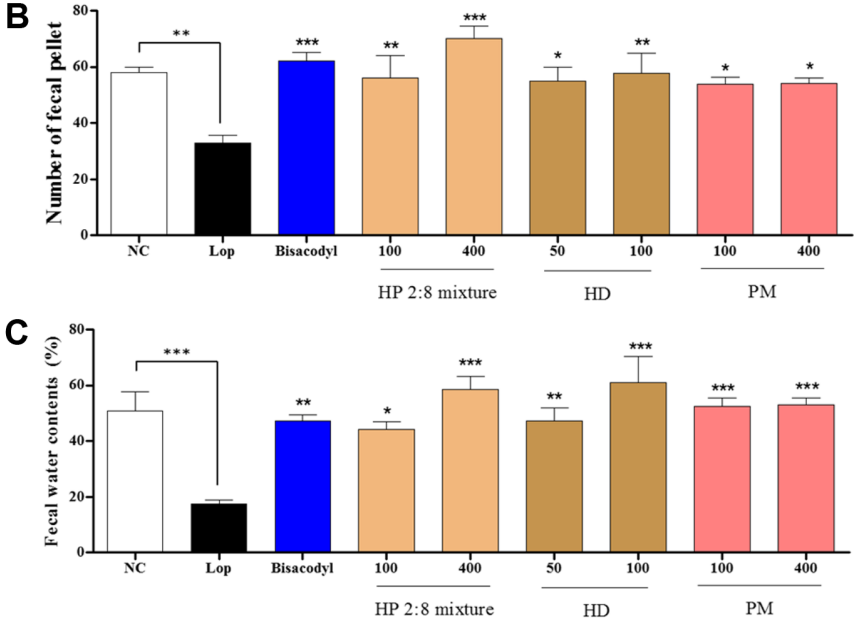

Fig. 2. Effect of Hovenia dulcis Thunb. (HD) and Phyllostachys pubescens Mazel (PM) mixed (2:8) hot-water extract (HP 2:8 mixture) on fecal parameters in loperamide-dosed rats. The effects on (A) fecal weight, (B) fecal numbers (C) fecal water contents in loperamide-induced constipation. The values are expressed as the mean $\pm \operatorname{SEM}\left(n=7,{ }^{*} p<\right.$ $0.05,{ }^{* *} \mathrm{p}<0.01,{ }^{* * *} p<0.001$ significantly fecaldifferent from the loperamide group). Statistical significance was tested with post hoc Dunnett test. NC: normal control, Lop: loperamide treated group, Bisacodyl: positive control, HP: Hovenia dulcis Thunb. (HD) and Phyllostachys pubescens Mazel (PM) 2:8 mixture. 
Table 2. Effects of Hovenia dulcis Thunb. (HD) and Phyllostachys pubescens Mazel (PM) mixed (2:8) hot-water extract (HP 2:8 mixture) on body weight, food intake and water intake in loperamide-induced constipation.

\begin{tabular}{|c|c|c|c|c|c|c|c|}
\hline & \multicolumn{3}{|c|}{ Body weight (g/day) } & \multicolumn{2}{|c|}{ Food intake (g/day) } & \multicolumn{2}{|c|}{ Water intake (ml/day) } \\
\hline & Initial & Final & $\begin{array}{c}\text { Body } \\
\text { weight gain }\end{array}$ & $\begin{array}{c}\text { Before } \\
\text { constipation }\end{array}$ & $\begin{array}{c}\text { After } \\
\text { constipation }\end{array}$ & $\begin{array}{c}\text { Before } \\
\text { constipation }\end{array}$ & $\begin{array}{c}\text { After } \\
\text { constipation }\end{array}$ \\
\hline $\begin{array}{l}\text { Normal } \\
\text { control }\end{array}$ & $157.45 \pm 8.13$ & $260.77 \pm 14.96$ & $103.32 \pm 12.19$ & $24.44 \pm 1.95$ & $26.01 \pm 2.02$ & $34.43 \pm 4.54$ & $32.14 \pm 6.99$ \\
\hline $\begin{array}{l}\text { Loperamide } \\
4 \mathrm{mg} / \mathrm{kg}\end{array}$ & $157.56 \pm 8.01$ & $229.71 \pm 7.72$ & $72.15 \pm 9.24^{\star * *}$ & $23.29 \pm 1.20$ & $22.65 \pm 1.29$ & $31.71 \pm 3.15$ & $30.71 \pm 4.50$ \\
\hline $\begin{array}{l}\text { Bisacodyl } \\
4 \mathrm{mg} / \mathrm{kg}\end{array}$ & $157.33 \pm 7.45$ & $237.25 \pm 14.08$ & $79.92 \pm 13.91^{\star *}$ & $21.88 \pm 2.45$ & $20.76 \pm 1.54$ & $31.29 \pm 5.09$ & $32.14 \pm 4.38$ \\
\hline $\begin{array}{l}\mathrm{HP} \\
100 \mathrm{mg} / \mathrm{kg}\end{array}$ & $157.38 \pm 7.28$ & $235.8 \pm 15.36$ & $78.42 \pm 13.07^{\star *}$ & $22.72 \pm 1.64$ & $21.99 \pm 2.09$ & $34.29 \pm 5.56$ & $30.71 \pm 7.35$ \\
\hline $\begin{array}{l}\mathrm{HP} \\
400 \mathrm{mg} / \mathrm{kg}\end{array}$ & $157.36 \pm 7.44$ & $234.81 \pm 13.83$ & $77.46 \pm 9.54^{\star * *}$ & $21.42 \pm 0.84$ & $21.05 \pm 2.61$ & $31.00 \pm 5.32$ & $27.14 \pm 5.67$ \\
\hline $\begin{array}{l}\mathrm{HD} \\
50 \mathrm{mg} / \mathrm{kg}\end{array}$ & $157.43 \pm 7.47$ & $235.1 \pm 12.49$ & $77.67 \pm 14.24^{\star *}$ & $22.46 \pm 1.10$ & $20.84 \pm 1.95$ & $32.87 \pm 5.58$ & $29.29 \pm 7.32$ \\
\hline $\begin{array}{l}\text { HD } \\
100 \mathrm{mg} / \mathrm{kg}\end{array}$ & $157.45 \pm 7.54$ & $238.97 \pm 14.95$ & $81.53 \pm 9.23^{\star *}$ & $22.34 \pm 1.60$ & $20.54 \pm 5.29$ & $32.57 \pm 4.89$ & $35.28 \pm 5.16$ \\
\hline $\begin{array}{l}\text { PM } \\
100 \mathrm{mg} / \mathrm{kg}\end{array}$ & $157.14 \pm 7.66$ & $237.43 \pm 16.22$ & $80.29 \pm 13.34^{* *}$ & $22.10 \pm 2.41$ & $20.90 \pm 1.64$ & $32.00 \pm 5.29$ & $32.86 \pm 4.88$ \\
\hline $\begin{array}{l}\mathrm{PM} \\
400 \mathrm{mg} / \mathrm{kg}\end{array}$ & $157.39 \pm 8.34$ & $230.42 \pm 16.46$ & $73.03 \pm 11.57^{* * *}$ & $22.37 \pm 1.93$ & $19.54 \pm 6.91$ & $34.43 \pm 3.56$ & $35.57 \pm 4.08$ \\
\hline
\end{tabular}

Data represent the mean \pm SEM. Values with different letters in a column are significantly differnet according to Student's $t$-test $(p<0.05) .{ }^{\star} p<0.05,{ }^{* *} p<0.01,{ }^{* *} p<0.001$ significantly different from the normal control group.

compared to those of the loperamide group and also increased in HD only $(100 \mathrm{mg} / \mathrm{kg})$ and PM only $(400 \mathrm{mg} / \mathrm{kg})$ groups (Fig. 2A). Fecal numbers were significantly increased by HP mixed extracts at 100 and $400 \mathrm{mg} / \mathrm{kg}$ in a dose dependent manner compared to the loperamide group and also increased by HD only at $100 \mathrm{mg} / \mathrm{kg}$ and PM only at $400 \mathrm{mg} / \mathrm{kg}$ (Fig. 2B). The fecal water content was significantly increased in the groups treated with HP mixed extracts (100 and $400 \mathrm{mg} / \mathrm{kg}$ ), HD only (50 and $100 \mathrm{mg} / \mathrm{kg}$ ) and PM only (100 and $400 \mathrm{mg} / \mathrm{kg}$ ) compared to the loperamide group (Fig. 2C).

Effect of HP 2:8 Mixture on Body Weight and Feeding Behavior in Loperamide-Induced Constipation

Table 2 shows the results of the analysis of weight changes, food intake, and water intake in each group during the experimental period. Body weight of the loperamide group and the sample treated group were decreased compared with that of the normal control group on the final day, but no abnormal symptoms were observed. Food intake and water intake differed between all groups compared to the control or loperamide group, but no abnormal symptoms were observed. The reason for the decrease in body weight is probably due to the fact that the food intake did not increase significantly.

Effects on Fecal Parameters in Low-Fiber Diet-Induced Constipation

The fecal weight, number, and water content were assessed to determine the effects of HP mixed extracts on low-fiber diet-induced constipation. Fecal weights were significantly increased in HP mixed extract groups (100 and $400 \mathrm{mg} / \mathrm{kg}$ ) in a dose dependent manner compared to those of the low-fiber diet group and also increased in HD only (100 mg/kg) and PM only ( $400 \mathrm{mg} / \mathrm{kg}$ ) groups (Fig. 3A). Fecal numbers were increased by HP mixed extracts at 100 and $400 \mathrm{mg} / \mathrm{kg}$ compared to those of the low-fiber diet group and also increased in HD only 100 and PM only $400 \mathrm{mg} / \mathrm{kg}$ (Fig. 3B). The water content of fecal was significantly increased by HP mixed extracts ( 100 and $400 \mathrm{mg} / \mathrm{kg}$ ), HD only (50 and $100 \mathrm{mg} / \mathrm{kg}$ ) and PM only (100 and $400 \mathrm{mg} / \mathrm{kg}$ ) compared to that of the low-fiber diet group (Fig. 3C). Parameters of fecal excretion were increased in all groups that received HP mixed extract, although reduced food intake was observed over the entire experimental period.

Effect of HP 2:8 Mixture on Body Weight and Feeding Behavior in Low-Fiber Diet-Induced Constipation

Table 3 shows the results of the analysis of weight changes, food intake and water intake in each group during the experimental period. Body weight of the low-fiber diet group and the sample treated group were increased compared with the normal control group from the final day. Food intake and water intake differed between all groups compared to the normal control group, but no abnormal symptoms were observed. The parameter of fecal excretion was increased in all groups that received HP mixed extract, although reduced food intake and water intake were observed over the entire experimental period.

Gastrointestinal Charcoal Transit ratio and Distal Colon Fecal Number in Loperamide-Induced Constipation

To determine the effects of HP mixed extracts on the intestinal transit ratio, we measured gastrointestinal charcoal transit ratio in the rat. The intestinal charcoal transit ratio was significantly reduced in the loperamide group compared to that of the normal control group, and enhanced in the positive control group and all sample treatment groups (Fig. 4). Fecal numbers in the distal colon increased in the loperamide group compared to the 

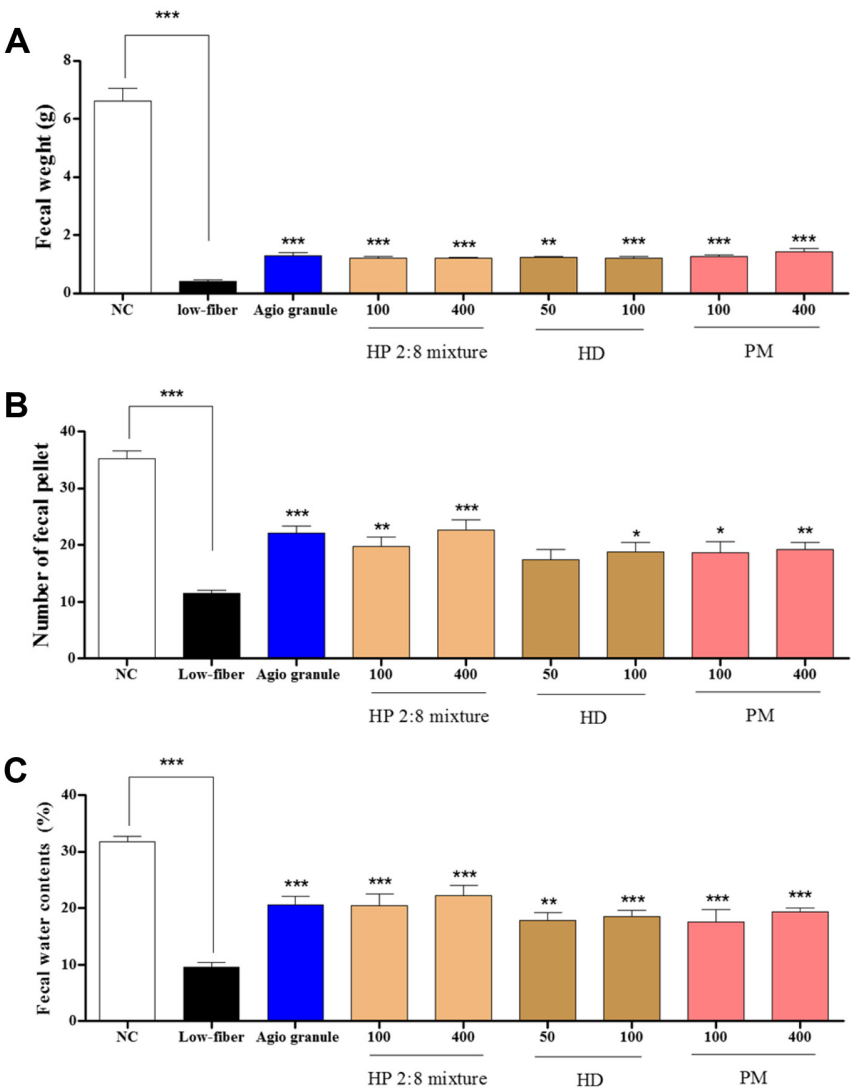

Fig. 3. Effect of Hovenia dulcis Thunb. (HD) and Phyllostachys pubescens Mazel (PM) mixed (2:8) hot-water extract (HP 2:8 mixture) on fecal moisture in low-fiber diet-induced constipation. The effects on (A) fecal weight, (B) fecal numbers (C) fecal water contents in low-fiber diet-induced constipation. The values are expressed as the mean $\pm \operatorname{SEM}\left(n=7,{ }^{*} p<0.05,{ }^{* *} p<0.01,{ }^{* *} p<0.001\right.$ significantly different from the low-fiber diet group $)$. Statistical significance was tested with post hoc Dunnett test. NC: normal control, Low-fiber: low-fiber diet group, Agio granule: positive control, HP: Hovenia dulcis Thunb. (HD) and Phyllostachys pubescens Mazel (PM) 2:8 mixture.

normal control group and were decreased in all sample treatment groups compared to the loperamide group, but there was no significant difference from the loperamide group (Fig. 5).

Gastrointestinal Charcoal Transit Ratio and Distal Colon Fecal Number in Low-Fiber Diet-Induced Constipation

To determine the effects of HP mixed extracts on the intestinal transit ratio in low-fiber diet-induced constipation, we measured gastrointestinal charcoal transit ratio in the rat. Intestinal charcoal transit ratio was

Table 3. Effects of Hovenia dulcis Thunb. (HD) and Phyllostachys pubescens Mazel (PM) mixed (2:8) hot-water extract (HP 2:8 mixture) on body weight, food intake, and water intake in low-fiber diet-induced constipation.

\begin{tabular}{|c|c|c|c|c|c|c|c|}
\hline & \multicolumn{3}{|c|}{ Body weight (g/day) } & \multicolumn{2}{|c|}{ Food intake (g/day) } & \multicolumn{2}{|c|}{ Water intake (ml/day) } \\
\hline & itial & Final & $\begin{array}{c}\text { Body } \\
\text { weight gain }\end{array}$ & $\begin{array}{c}\text { Before } \\
\text { constipation }\end{array}$ & $\begin{array}{c}\text { After } \\
\text { constipation }\end{array}$ & $\begin{array}{c}\text { Before } \\
\text { constipation }\end{array}$ & $\begin{array}{c}\text { After } \\
\text { constipation }\end{array}$ \\
\hline 0 & $57.95 \pm$ & 1.30 & $105.68 \pm 10.03$ & $21.85 \pm 2.16$ & $30.07 \pm 1.80$ & $32.43 \pm 3.82$ & $38.29 \pm 2.36$ \\
\hline Low & 263.59 & $390.46 \pm$ & $6.87 \pm 16.93$ & $17.72 \pm$ & $24.64 \pm 0.67$ & $28.57 \pm 4.76$ & $29.71 \pm 4.15$ \\
\hline $\begin{array}{l}\text { iulel } \\
g\end{array}$ & 263.24 & $383.65 \pm$ & & $18.70 \pm 1.73$ & $24.27 \pm 0.47$ & $27.86 \pm$ & $30.29 \pm$ \\
\hline $\mathrm{lg} / \mathrm{kg}$ & 259. & & & $.34 \pm 3$ & $94 \pm 1$ & $24.29 \pm 4$ & $29.29 \pm 3.45$ \\
\hline$/ \mathrm{kg}$ & 259.55 & $383.65 \pm$ & 30 & $18.16 \pm 3$ & $24.02 \pm$ & $23.57 \pm$ & $28.14 \pm 4.18$ \\
\hline $\mathrm{g} / \mathrm{kg}$ & $271.56 \pm 12.63$ & $407.39 \pm 3$ & $135.83 \pm$ & $17.82 \pm 3.41$ & $24.84 \pm 0.80$ & $27.86 \pm 6.99$ & $28.86 \pm 3.98$ \\
\hline HD 100 mg/kg & $256.81 \pm 9.91$ & $376.00 \pm 28.73$ & $119.19 \pm 33.38$ & $21.21 \pm 1.54$ & $24.47 \pm 0.84$ & $23.00 \pm 4.65$ & $28.86 \pm 2.73$ \\
\hline PM 100 mg/kg & $258.10 \pm 10.00$ & $380.40 \pm 22.51$ & $122.30 \pm 11.05$ & $20.90 \pm 2.64$ & $24.16 \pm 0.69$ & $24.29 \pm 6.07$ & $31.00 \pm 1.91$ \\
\hline PM 400 mg/kg & $265.91 \pm 5.26$ & $393.84 \pm 19.11$ & $127.93 \pm 13.03$ & $18.88 \pm 1.84$ & $24.32 \pm 1.40$ & $27.86 \pm 2.67$ & $29.86 \pm 2.34$ \\
\hline
\end{tabular}

Data represent the mean \pm SEM. Values with different letters in a column are significantly differnet according to Student's $t$-test $(p<0.05) .{ }^{\star} p<0.05,{ }^{* *} p<0.01,{ }^{* *} p<0.001$ significantly different from the normal control group. 


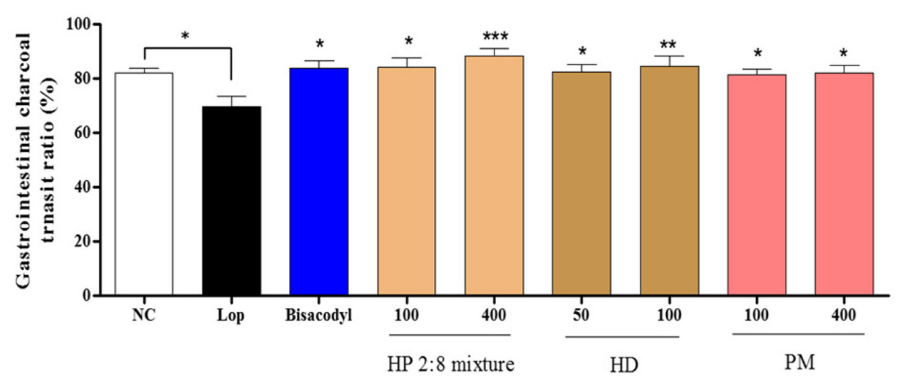

Fig. 4. Effect of Hovenia dulcis Thunb. (HD) and Phyllostachys pubescens Mazel (PM) mixed (2:8) hot-water extract (HP 2:8 mixture) on gastrointestinal charcoal transit ratio in rats with loperamide-induced constipation. The values are expressed as the mean $\pm \operatorname{SEM}\left(n=7,{ }^{*} p<0.05,{ }^{* *} p<0.01,{ }^{* * *} p<0.001\right.$ significantly different from the loperamide group). Statistical significance was tested with post hoc Dunnett test. NC: normal control, Lop: loperamide treated group, Bisacodyl: positive control, HP: Hovenia dulcis Thunb. (HD) and Phyllostachys pubescens Mazel (PM) 2:8 mixture.

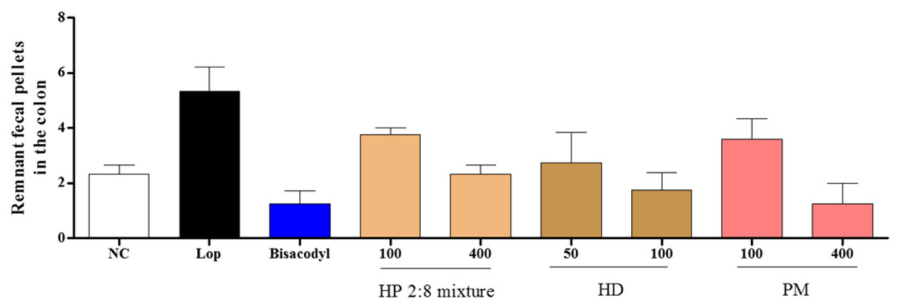

Fig. 5. Effect of Hovenia dulcis Thunb. (HD) and Phyllostachys pubescens Mazel (PM) mixed (2:8) hot-water extract (HP 2:8 mixture) on remnant fecal pellets in the colon in rats with loperamide-induced constipation. The values are expressed as the mean \pm SEM. $\left(n=7,{ }^{*} p<0.05,{ }^{* *} p<0.01\right.$, ${ }^{* * *} p<0.001$ significantly different from the loperamide group) Statistical significance was tested with post hoc Dunnett test. NC: normal control, Lop: loperamide treated group, Bisacodyl: positive control, HP: Hovenia dulcis Thunb. (HD) and Phyllostachys pubescens Mazel (PM) 2:8 mixture.

reduced in the loperamide group compared to that of the normal control group, and enhanced in the positive control group and high-dose treatment groups (Fig. 6). Fecal numbers in the distal colon increased in the loperamide group compared to those of the normal control group and were decreased in all sample treatment groups compared those of the loperamide group (Fig. 7).

\section{Histology of the Distal Colon in Loperamide-Induced Constipation}

To investigate whether HP mixed extracts treatment could induce alteration of the histological structure of the distal colon in loperamide-induced constipation, mucosa layer thickness and muscle thickness were assessed in the distal colons of rats following H\&E staining. The average thickness of mucosa was significantly less in the loperamide group than the normal control group. Following treatment of the loperamide-induced constipation with HP mixed extracts ( 100 and $400 \mathrm{mg} / \mathrm{kg}$ ), this level increased by more than $67.11 \%$ and $78.14 \%$ compared with that of the loperamide group. This level also increased in the HD-only treatment (50 and $100 \mathrm{mg} / \mathrm{kg}$ ) and PM-only treatment (100 and $400 \mathrm{mg} / \mathrm{kg}$ ) groups by $43.67 \%, 60.38 \%, 52.02 \%$, and $60.72 \%$ respectively (Figs. $8 \mathrm{~A}$ and $8 \mathrm{~B}$ ).

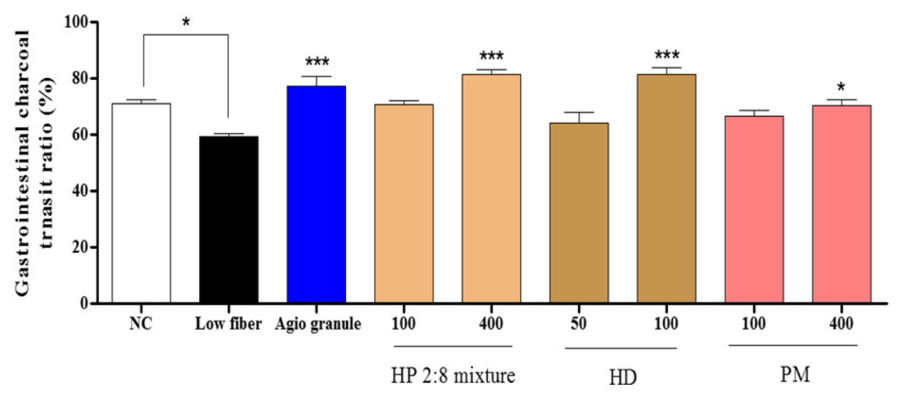

Fig. 6. Effect of Hovenia dulcis Thunb. (HD) and Phyllostachys pubescens Mazel (PM) mixed (2:8) hot-water extract (HP 2:8 mixture) on gastrointestinal charcoal transit ratio in rats with low-fiber diet-induced constipation. The values are expressed as the mean $\pm \operatorname{SEM}\left(n=7,{ }^{*} p<0.05,{ }^{* *} p<0.01,{ }^{* * *} p<0.001\right.$ significantly different from the low-fiber diet group). Statistical significance was tested with post hoc Dunnett test. NC: normal control, Low-fiber: low-fiber diet group, Agio granule: positive control, HP: Hovenia dulcis Thunb. (HD) and Phyllostachys pubescens Mazel (PM) 2:8 mixture. 


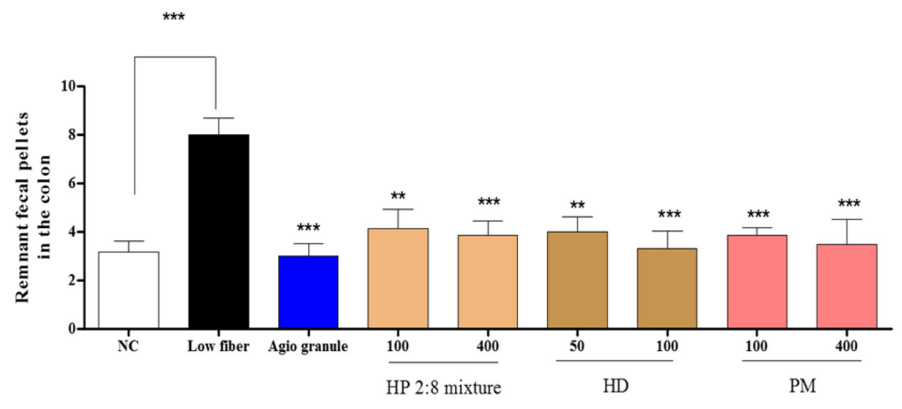

Fig. 7. Effect of Hovenia dulcis Thunb. (HD) and Phyllostachys pubescens Mazel (PM) mixed (2:8) hot-water extract (HP 2:8 mixture) on remnant fecal pellets in the colon in rats with low-fiber diet-induced constipation. The values are expressed as the mean $\pm \operatorname{SEM}\left(n=7,{ }^{*} p<0.05,{ }^{* *} p<0.01,{ }^{* *} p<0.001\right.$ significantly different from the low-fiber diet group). Statistical significance was tested with post hoc Dunnett test. NC: normal control, Low-fiber: low-fiber diet group, Agio granule: positive control, HP: Hovenia dulcis Thunb. (HD) and Phyllostachys pubescens Mazel (PM) 2:8 mixture.

\section{A}
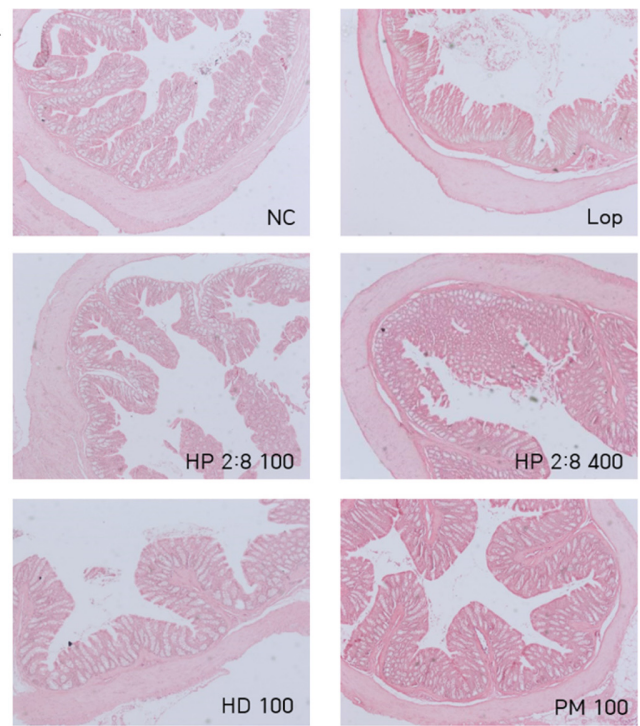

Lop
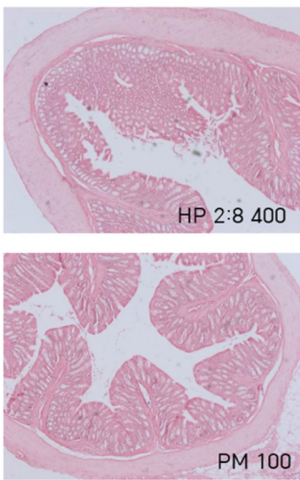

B

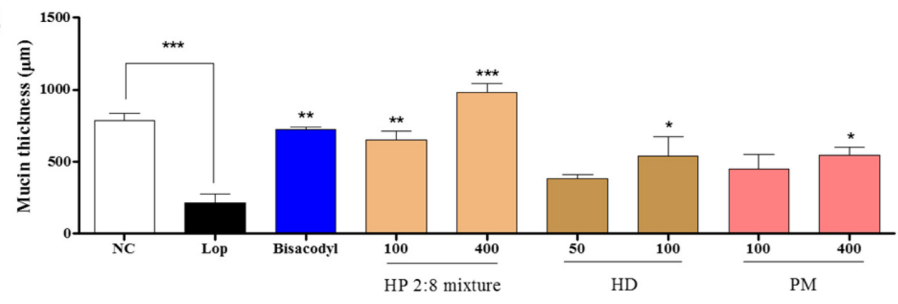

C

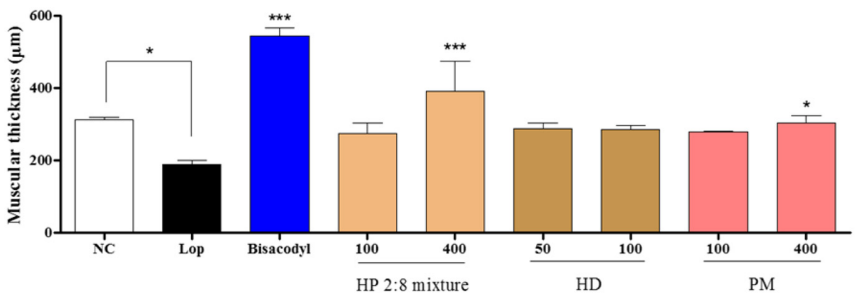

Fig. 8. Alteration of the histological structure in the colon. (A) Hematoxylin and eosin (H\&E) stained sections of colons from the untreated group, loperamide group, positive group, the HP 2:8 mixture group (100 and $400 \mathrm{mg} / \mathrm{kg}$ ), HD-only treated group (50 and $100 \mathrm{mg} / \mathrm{kg}$ ), and PM-only treated group (100 and $400 \mathrm{mg} / \mathrm{kg}$ ) were observed at $50 \times$ magnification using a light microscope. (B) The thickness of the mucosa and (C) muscular layer are presented as graphs. The values are expressed as the mean $\pm \operatorname{SEM}\left(n=7,{ }^{*} p<0.05,{ }^{* *} p<0.01,{ }^{* *} p<0.001\right.$ significantly different from the loperamide group). Statistical significance was tested with post hoc Dunnett test. NC: normal control, Lop: loperamide treated group, Bisacodyl: positive control, HP: Hovenia dulcis Thunb. (HD) and Phyllostachys pubescens Mazel (PM) 2:8 mixture. 
Moreover, muscle thickness was very similar to mucosa layer thickness. In the loperamide group, the muscle thickness was dramatically decreased compared to that of the normal control group. However, with the HP mixed extracts treatment (12.68\% and $37.77 \%)$, HD-only treatment $(23.96 \%$ and $24.81 \%)$, and PM-only treatment (22.02\% and 27.64\%) with loperamide groups, muscle thickness was recovered (Fig. 8C). Taken together, these results show that HP mixed extracts induced increases in mucosa layer and muscle thickness in the distal colon of constipated rats.

\section{Histology of the Distal Colon in Low-Fiber Diet-Induced Constipation}

To investigate whether HP mixed extracts treatment could induce alteration of the histological structure of the distal colon in low-fiber diet-induced constipation, mucosa layer thickness, and muscle thickness were assessed in the distal colons of rats following H\&E staining. The average thickness of mucosa was significantly lower in the low-fiber diet group than that of the normal control group. Following HP mixed extracts treatment for the lowfiber diet ( 100 and $400 \mathrm{mg} / \mathrm{kg}$ ), this level increased by more than $78.05 \%$ and $81.40 \%$ compared with that of the low-fiber diet group. This level also increased in HD-only treatment $(50$ and $100 \mathrm{mg} / \mathrm{kg}$ ) and PM-only treatment (100 and $400 \mathrm{mg} / \mathrm{kg}$ ) group by $80.31 \%, 80.47 \%, 78.69 \%$, and $80.94 \%$ respectively (Figs. 9A and 9B). Moreover, muscle thickness was very similar to mucosa layer thickness. In the low-fiber diet group, the muscle thickness was dramatically decreased compared to that of the normal control group. However, in the HP mixed extracts
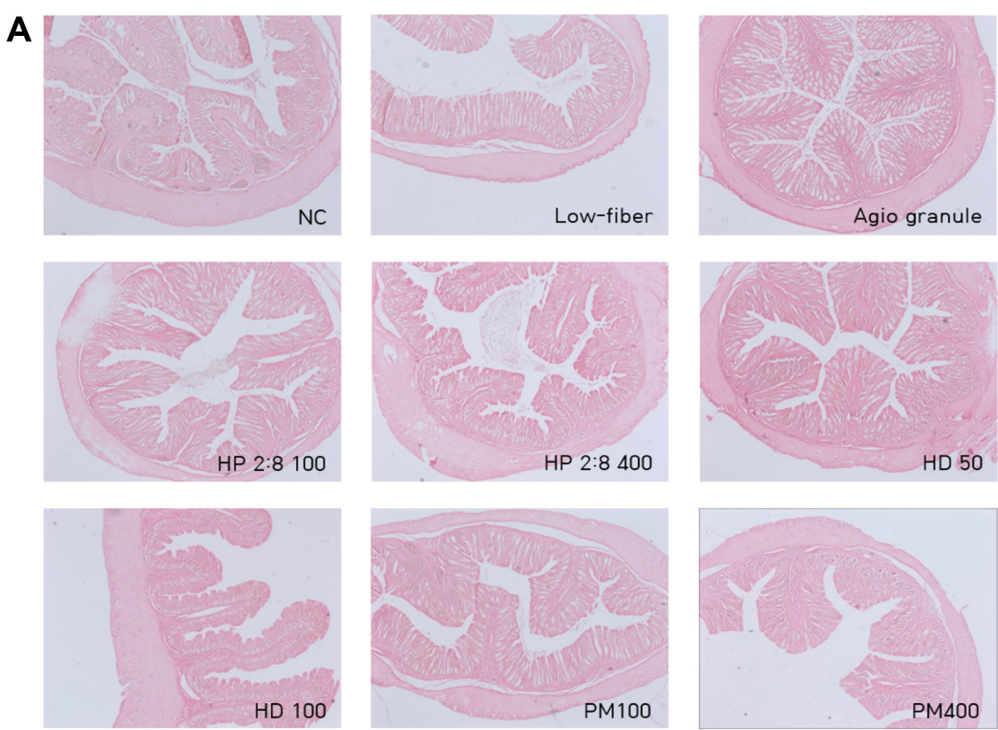

B

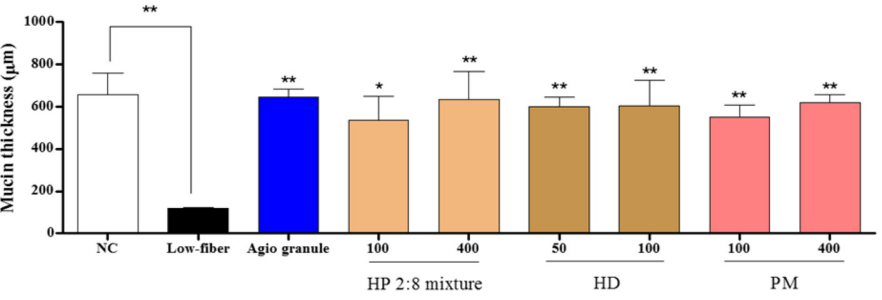

C

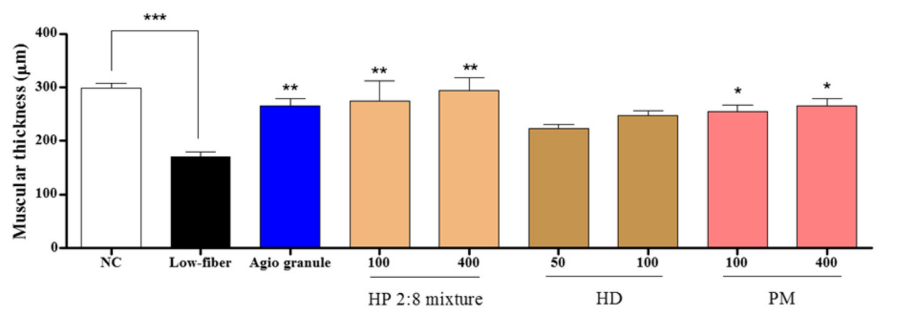

Fig. 9. Alteration of the histological structure in the colons. (A) Hematoxylin and eosin (H\&E) stained sections of colons from the untreated group, low-fiber diet group, positive group, the HP 2:8 mixture group (100 and $400 \mathrm{mg} / \mathrm{kg}$ ), HD-only treated group (50 and $100 \mathrm{mg} / \mathrm{kg}$ ), and PM-only treated group (100 and $400 \mathrm{mg} / \mathrm{kg}$ ) were observed at $50 \times$ magnification using a light microscope. (B) The thickness of the mucosa and (C) muscular layer are presented as graphs. The values are expressed as the mean $\pm \operatorname{SEM}\left(n=7,{ }^{*} p<0.05,{ }^{* *} p<0.01,{ }^{* *} p<0.001\right.$ significantly different from the low-fiber diet group). Statistical significance was tested with post hoc Dunnett test. NC: normal control, Low-fiber: low-fiber diet group, Agio granule: positive control, HP: Hovenia dulcis Thunb. (HD) and Phyllostachys pubescens Mazel (PM) 2:8 mixture. 

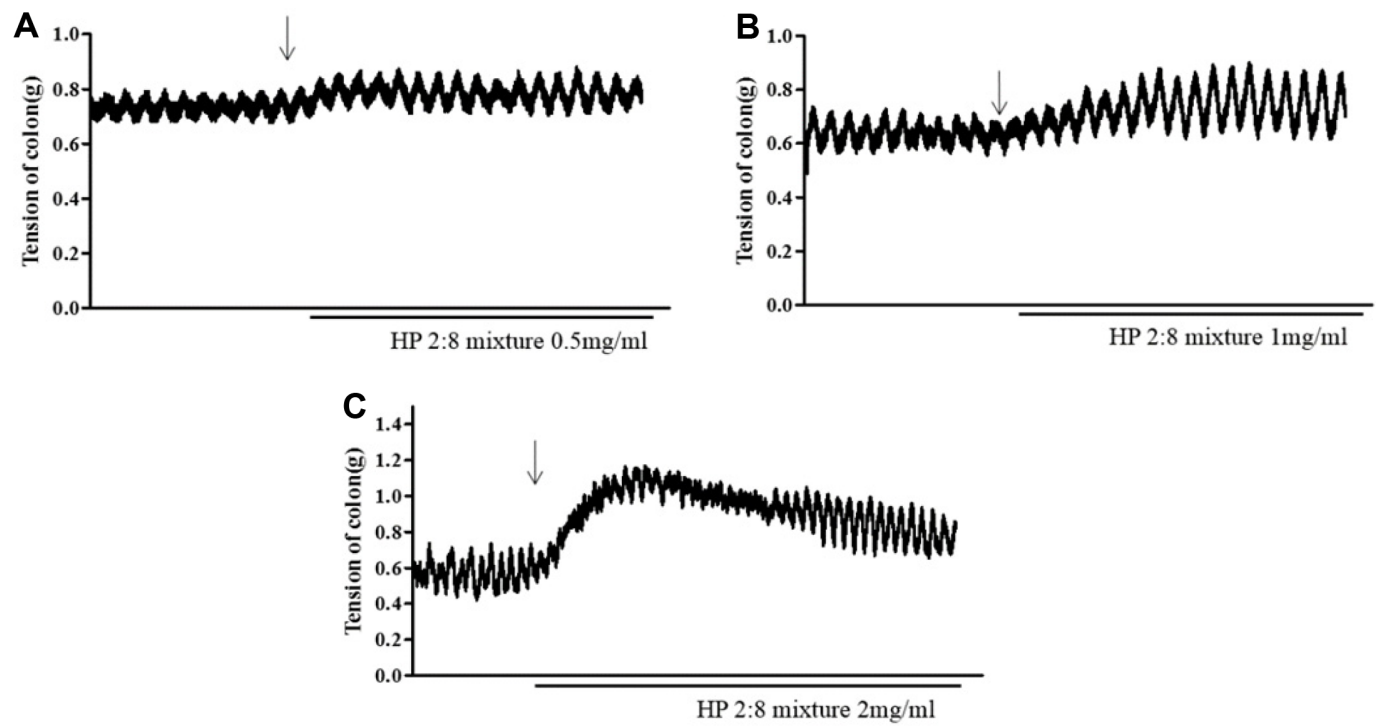

Fig. 10. Representative temporal profiles of contractile activity of isolated rat colon in the Hovenia dulcis Thunb. (HD) and Phyllostachys pubescens Mazel (PM) mixed (2:8) hot-water extract (HP 2:8 mixture) at $0.5 \mathrm{mg} / \mathrm{ml}(\mathrm{A}), 1 \mathrm{mg} / \mathrm{ml}(\mathrm{B})$, and $2 \mathrm{mg} / \mathrm{ml}$ (C).

treatment (34.61\% and 36373\%), HD-only treatment (18.76\% and $24.38 \%$ ), and PM-only treatment (26.65\% and 29.26\%) with low-fiber diet groups, muscle thickness was recovered (Fig. 9C). Taken together, these results show that HP mixed extracts induced increases in mucosa layer and muscle thickness in the distal colon of constipated rats.

\section{Effects of the HP 2:8 Mixture on Spontaneous Colon Contraction}

To investigate the effect of Hovenia dulcis Thunb. (HD) and Phyllostachys pubescens Mazel (PM) mixed (2:8) hot-water extract (HP 2:8 mixture) on spontaneous intestinal contraction, we assessed the tension of the isolated rat colon segments. The HP 2:8 mixture was applied to the isolated colon at final concentrations of $0.5,1$, and $2 \mathrm{mg} /$ $\mathrm{ml}$. In the isolated intestinal colon, tension of the intestinal colon was significantly increased in a dose-dependent manner (Fig. 10).

\section{Effects of HP 2:8 Mixture on IEC-18 Cell [ $\left.\mathrm{Ca}^{2+}\right] \mathrm{i}$}

To define the cellular mechanisms that mediate HP 2:8 mixture-induced relaxation, we used an intestinal epithelial cell line. A fluorescence signal increase was initiated when the bath solution was changed from $\mathrm{Ca}^{2+}$ free PSS to a normal PSS (Fig. 11A); while this increase was not observed in the presence of HP 2:8 mixture when $\mathrm{Ca}^{2+}$ influx was blocked. The HP 2:8 mixture could also prevent the ATP induced $\left[\mathrm{Ca}^{2+}\right]$ i increase (Figs. 11B-11D).

Constipation is a common health problem that tends to cause discomfort and affect patient quality of life [36]. Constipation may cause abdominal bloating, sickness, stress, and digestive problems [37]. Currently, a variety of therapeutic approaches are used for constipation. Treatments for constipation usually include stimulant and osmotic laxatives, fiber supplements, fecal softeners, and sometimes enemas for wayward constipation. As current symptomatic treatments can produce unsatisfactory results, many patients seek help from herbal medicine [38]. Any herbal medicine may contain many bioactive compounds with potentially deleterious as well as beneficial effects [39].

In the present study, we investigated the laxative effects of the mixture of Hovenia dulcis Thunb. and Phyllostachys pubescens Manzel (HP 2:8 mixture) on chronic constipation. Loperamide-induced and low-fiber diet-induced constipation are well-established methods that are widely used as a model of spastic constipation [40]. In this study the results demonstrated that HP mixed extract can elevate the symptoms of constipation through the improvement of fecal excretion, and the recovery of histological changes of the colon in a constipation model.

The most important factor during the mechanistic and developmental study of laxative drugs is fecal excretion. The constipation model induced with loperamide and a low-fiber diet showed a significant decrease in fecal parameters including feces weight, number, and water consumption [41-43]. These changes were alleviated with several plant extracts. In this study, a similar laxative effect on fecal parameters was verified in the loperamide and low-fiber diet-induced constipation model by administration of 100 or $400 \mathrm{mg} / \mathrm{kg}$ of HP mixed extract, 50 or $100 \mathrm{mg} / \mathrm{kg}$ of Hovenia dulcis Thunb. (HD), and 100 or $400 \mathrm{mg} / \mathrm{kg}$ of Phyllostachys pubescens Manzel (PM) (Figs. 2 and 3). These results provide evidence that HP mixed extract can contribute to alleviating constipation, and are potential candidates for laxative drugs.

The intestinal transit ratio has most often been measured by administering an aqueous suspension of active 
A

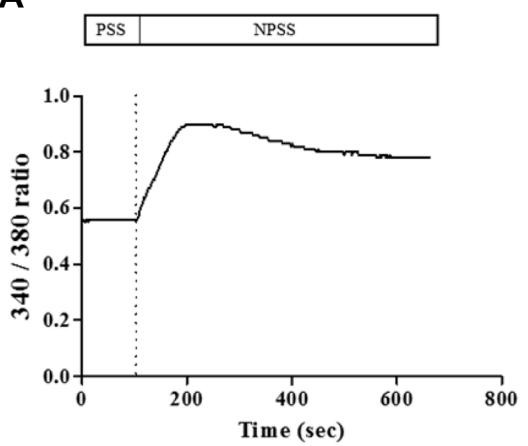

C
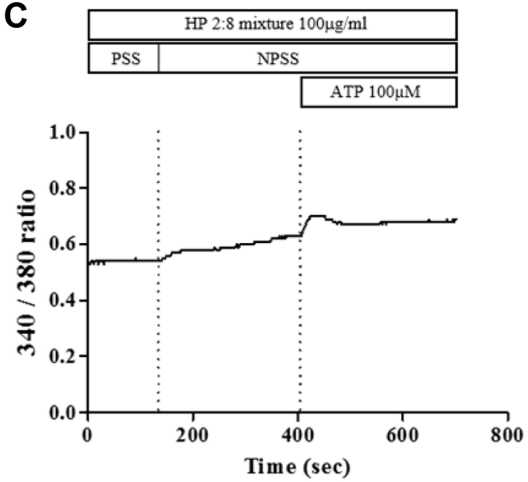

B

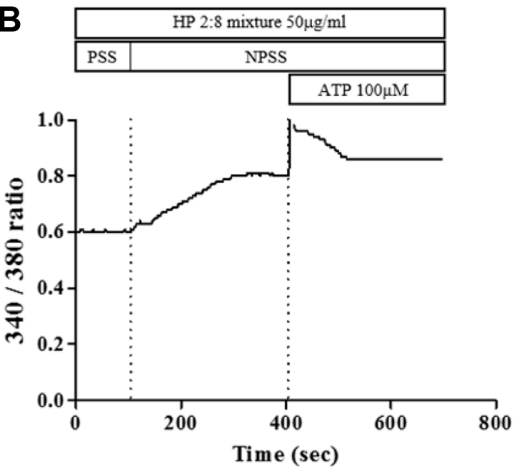

D

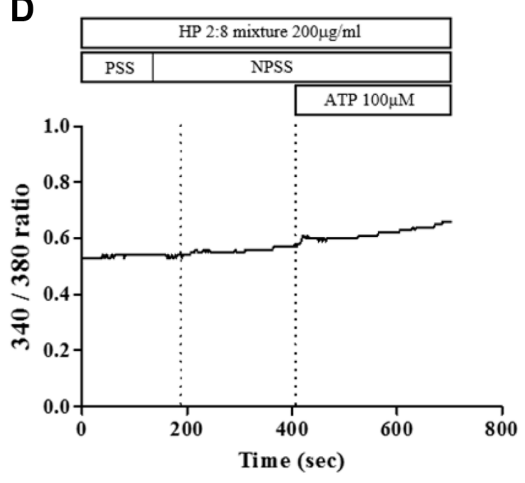

Fig. 11. Effect of HP 2:8 mixture on [ $\mathrm{Ca}^{2+}$ ] i of IEC-18 cells. (A) $\mathrm{Ca}^{2+}$ influx by changing the buffer from $\mathrm{Ca}^{2+}$-free (PSS) to normal solution (NPSS) induced a dramatic increase in $\left[\mathrm{Ca}^{2+}\right]$ i detected by fura-2/AM. (B) ATP-induced Ca ${ }^{2+}$ release was blocked in the presence of HP 2:8 mixture $50 \mathrm{mg} / \mathrm{ml}$. (C) ATP-induced $\mathrm{Ca}^{2+}$ release was blocked in the presence of $\mathrm{HP} 2: 8$ mixture $100 \mathrm{mg} / \mathrm{ml}$. (D) ATP-induced $\mathrm{Ca}^{2+}$ release was blocked in the presence of HP 2:8 mixture $200 \mathrm{mg} / \mathrm{ml}$. All the data are represented as means \pm SEM.

charcoal to rodents, and transit ratio is reflective of intestinal motility. Motility of the gastrointestinal (GI) tract, evaluated by the charcoal meal, indicated the rapid and significant excretion of fecals in response to treatment with the HP 2:8 mixture compared with that of the loperamide-induced group and low-fiber diet-induced group. The GI tract is regulated by the innervation of the enteric nervous system (ENS), which controls the rhythmic activity of the gut smooth muscle cells [44]. The HP 2:8 mixture at a dose of 100 and $400 \mathrm{mg} / \mathrm{kg}$ significantly increased the distance traveled by charcoal meal in loperamide-induced constipation (Figs. 4 and 5). Also, HP mixed extract at a dose of $400 \mathrm{mg} / \mathrm{kg}$ increased the transit ratio in low-fiber diet-induced constipation (Figs. 6 and 7).

Mucin is responsible for the physical and chemical properties of mucus [14]. Colonic mucus is decreased in a rat model of constipation, and mucosal layer thickness in the distal colon of rats is decreased by loperamide [45] and a low-fiber diet [46]. In this study, the mucosa layer length and muscular layer thickness sharply increased in the groups with the HP 2:8 mixture at 100 and $400 \mathrm{mg} / \mathrm{kg}$ compared with those of the loperamide-treated group (Fig. 8). It has same result in the low-fiber diet-induced constipation model (Fig. 9).

The coordination of smooth muscle contraction and relaxation is the basis of gut motility [47]. Modern pharmacological agents including senna and bisacodyl are generally used for the treatment of constipation and these agents can increase the contraction of intestinal smooth muscle [48]. The spontaneous contractions in isolated rat colon were enhanced by treatment with to $0.5,1$, and $2 \mathrm{mg} / \mathrm{ml}$ of HP $2: 8$ mixture (Fig. 10). The significant increase in contraction suggests that HP mixed extract has a laxative effect and could be efficacious for the treatment of constipation. We also confirmed effect of single samples (HD and PM) on spontaneous intestinal contraction. HD and PM has effect of contractile activity but it was insignificant effect then HP 2:8 mixture (data not shown).

It has been reported that ATP released from enteric nerves mediates muscular inhibitory and excitatory responses in various animal species via activation of P2X and/or P2Y receptors [49]. ATP has been reported to induce inhibitory effects in all area of the gut acting on P2Y receptors [50-52], while excitatory effects on count of activation of P2X receptors placed on excitatory nerves in the stomach [53] or on smooth muscle in the longitudinal muscle of the colon have been shown [50]. The contraction effects induced by ATP were antagonized by the suramine (ATP inhibitor) or 4-[[4-formyl-5-hydroxy-6-methyl-3-[(phosphonooxy)methyl]-2-pyridinyl]azo]1,3-benzene disulphonic acid (PPADS) [54]. Also, mobilization of $\mathrm{Ca}^{2+}$ and an increase in $\left[\mathrm{Ca}^{2+}\right.$ ]i are required to trigger smooth muscle contraction [55]. ATP is a molecule known to produce $\mathrm{Ca}^{2+}$ responses in astrocytes, and has been implicated as a mediator of intercellular $\mathrm{Ca}^{2+}$ signaling in other types of non-excitable cells [56].

In the attempt to characterize the ATP response, we tested ATP-induced contractions in the presence of HP 2:8 
mixture on NPSS. Fig. 10 showed that HP 2:8 mixture had an inhibitory effect on ATP-mediated external $\mathrm{Ca}^{2+}$ evoked contractions (Fig. 11).

Taken together, the results of this study suggest that HP 2:8 mixture induces the recovery of fecal excretion, gastrointestinal motility, and histopathology in loperamide-induced and low-fiber diet-induced constipation models. Indeed, $\left[\mathrm{Ca}^{2+}\right] \mathrm{i}$ measurements by using fura-2 as an indicator showed HP 2:8 mixture has inhibitory responses in rat colon by inhibiting ATP-mediated $\mathrm{Ca}^{2+}$ influx. Therefore, our findings are demonstrate that the mixture of Hovenia dulcis Thunb. and Phyllostachys pubescens Manzel is a useful therapeutic option for the treatment of constipation.

In this experiment, we investigated the effect of the mixed extract of Hovenia dulcis Thunb. (HD) and Phyllostachys pubescens Mazel (PM) on chronic constipation in two constipation animal models and tried to clarify the mechanism of this effect. As a result, it was confirmed that the constipation improvement parameters (fecal weight, fecal number, and fecal moisture content) were improved in both the loperamide-induced animal model and the low-diet-induced animal model. Histological structure of the distal colon revealed that the mucin layer and muscular layer thickness decreased in the groups where constipation was induced (loperamide and lowfiber diet group) and increased in the HP 2:8 mixture treatment group. In addition, the contractile activity of colon tissues in the HP 2:8 mixture was found to increase with concentration. Moreover, the HP 2:8 mixture has inhibitory responses in rat colon, by inhibiting ATP-mediated $\mathrm{Ca}^{2+}$ influx. From these results, it was confirmed that the HP 2:8 mixture in the constipation model smooths mucin secretion and stimulates intestinal motility, thereby laxative constipation.

\section{Acknowledgment}

This research was supported by the Support Program for Industry-academy-research co-operation technology development business (Local promising SME support Program, C0501026) funded by the Ministry of SMEs and Startups.

\section{Conflict of Interest}

The authors have no financial conflicts of interests of declare.

\section{References}

1. Drossman DA. 2006. The functional gastrointestinal disorders and the Rome III process. Gastroenterology 130: 1377-1390.

2. Mugie SM, Benninga MA, Di Lorenzo C. 2011. Epidemiology of constipation in children and adults: a systematic review. Best Pract. Res. Clin. Gastroenterol. 25: 3-18.

3. Dorland's Pocket Medical Dictionary. $22^{\text {nd }}$ ed. (Friel JP, ed.) 1997. Philadelphia: W.B. Saunders.

4. Higgins PD, Johanson JF. 2004. Epidemiology of constipation in North America: a systematic review. Am. J. Gastroenterol. 99: 750759 .

5. Crowell MD, Harris LA, DiBaise JK, Olden KW. 2007. Activation of type-2 chloride channels: a novel therapeutic target for the treatment of chronic constipation. Curr. Opin. Invest. Drugs 8: 66-70.

6. Johnson DA. 2006. Treating chronic constipation: How should we interpret the recommendations? Clin. Drug Investig. 26: 547-557.

7. Locke 3rd GR, Pemberton, JH, Phillips SF. 2000. AGA technical review on constipation. Am. Gastroenterol. Assoc. Gastroenterol. 119: 1766-1778.

8. Altabas K, Bilić A, Jurcić D, Dorosulić Z, Mihanović M, Sunić-Omejc M, et al. 2003. The efficacy of cisapride vs. placebo and diet in patients with chronic constipation. Coll. Antropol. 27: 197-204

9. Busti AJ, Murillo Jr JR, Cryer B, 2004. Tegaserod-induced myocardial infarction: case report and hypothesis. Pharmacotherapy 24: 526-531.

10. Brown NW, Treasure JL, Campbell IC. 2001. Evidence for long-term pancreatic damage caused by laxative abuse in subjects recovered from anorexia nervosa. Int. J. Eat. Disord. 29: 236-238.

11. Siegers CP, von Hertzberg-Lottin E, Otte M, Schneider B. 1993. Anthranoid laxative abuse-a risk for colorectal cancer? Gut 34: 1099 1101.

12. Copeland PM. 1994. Renal failure associated with laxative abuse. Psychother. Psychosom. 62: 200-202.

13. Roerig JL, Steffen KJ, Mitchell JE, Zunker C. 2010. Laxative abuse: epidemiology, diagnosis and management. Drugs 70: $1487-1503$.

14. Lee HY, Kim JH, Jeung HW, Lee CU, Kim DS, Li B, et al. 2012. Effects of Ficus carica paste on loperamide-induced constipation in rats. Food Chem. Toxicol. 50: 895-902.

15. Yang J, Wu S, Li C. 2013. High efficiency secondary somatic embryogenesis in Hovenia dulcis Thunb. through solid and liquid cultures. Scientific WorldJournal 29: 718754.

16. Cho J Y, Moon JB, Chung SJ, Park KH. 2004. Isolation and characterization of 3(Z)-dodecenedioic acid as an antibacterial substance from Hovenia dulcis Thunb. Food Sci. Biotechnol. 13: 46-50.

17. Kim H, Kim YJ, Jeong HY, Kim JY, Choi EK, Chae SW, et al. 2017. A standardized extract of the fruit of Hovenia dulcis alleviated alcohol-induced hangover in healthy subjects with heterozygous ALDH2: A randomized, controlled, crossover trial. J. Ethnopharmacol. 209: 167-174

18. Zhou Y, Liang X, Chang H, Shu F, Wu Y, Zhang T, et al. 2014. Ampelopsin-induced autophagy protects breast cancer cells from apoptosis through Akt-mTOR pathway via endoplasmic reticulum stress. Cancer Sci. 105: 1279-1287.

19. Choi RY, Woo MJ, Ham JR, Lee MK. 2017. Anti-steatotic and anti-inflammatory effects of Hovenia dulcis Thunb. extracts in chronic alcohol-fed rats. Biomed. Pharmacother. 90: 393-401.

20. Kim B, Woo MJ, Park CS, Lee SH, Kim JS, Kim B, et al. 2017. Hovenia dulcis extract reduces lipid accumulation in oleic acid-induced steatosis of Hep G2 cells via activation of AMPK and PPARa/CPT-1 pathway and in acute hyperlipidemia mouse model. Phytother. Res. 31: 132-139.

21. Lim SJ, Kim M, Randy A, Nam EJ, Nho CW. 2016. Effects of Hovenia dulcis Thunb. extract and methyl vanillate on atopic dermatitislike skin lesions and TNF- $\alpha$ /IFN- $\gamma$-induced chemokines production in HaCaT cells. J. Pharm. Pharmacol. 68: 1465-1479.

22. Hong EJ, Jung EM, Lee GS, Kim JY, Na KJ, Park MJ, et al. 2010. Protective effects of the pyrolyzates derived from bamboo against neuronal damage and hematoaggregation. J. Ethnopharmacol. 128: 594-599 
23. Sun J, Yu J, Zhang PC. 2013. Isolation and identification of lignans from Caulis bambusae in Taenia with antioxidant properties. J. Agric. Food Chem. 61: 4556-4562.

24. Kim DS, Kim SH, Cha J. 2016. Antiobesity effects of the combined plant extracts varying the combination ratio of Phyllostachys pubescens leaf extract and Scutellaria baicalensis root extract. Evid. Based Complement Alternat. Med. 2016: 9735276.

25. Kim A, Im M, Yim NH, Jung YP, Ma JY. 2013. Aqueous extract of Bambusae Caulis in Taeniam inhibits PMA-induced tumor cell invasion and pulmonary metastasis: suppression of NF- $\mathrm{kB}$ activation through ROS signaling. PLoS One 8: e78061.

26. Shen XY, Cheng YL and Cai CJ. 2014. Diversity and antimicrobial activity of culturable endophytic fungi isolated frommoso bamboo seeds. PLoS One 9: e95838.

27. Lim D, Cho Y, Kim W, Jeong S, Jang YP, Kim J. 2017. Original Research: Extract of Bambusae Caulis in Taeniam inhibits cigarette smoke-induced pulmonary and intestinal inflammation. Exp. Biol. Med. (Maywood) 242: 102-112.

28. Jiao J, Zhang Y, Lou D, Wu X, Zhang Y. 2007. Antihyperlipidemic and antihypertensive effect of a triterpenoid-rich extract from bamboo shavings and vasodilator effect of friedelin on phenylephrine-induced vasoconstriction in thoracic aortas of rats. Phytother. Res. 21: 1135-1141.

29. Jung SH, Lee JM, Lee HJ, Kim CY, Lee EH, Um BH. 2007. Aldose reductase and advanced glycation endproducts inhibitory effect of Phyllostachys nigra. Biol. Pharm. Bull. 30: 1569-1572.

30. Choi JS, Kim JW, Cho HR, Kim KY, Lee JK, Shon JH, Ku SK. 2014. Laxative effects of fermented rice extract in rats with lopermaideinduced constipation. Exp. Ther. Med. 8: 1847-1854.

31. Yan S, Yue YZ, Wang XP, Dong HL, Zhen SG, Wu BS, et al. 2017. Aqueous extracts of Herba Cistanche promoted intestinal motility in loperamide-induced constipation rats by ameliorating the interstitial cells of Cajal. Evid. Based Complement. Alternat. Med. 2017: 6236904 .

32. Choi CY, Cho SS, Yoon IS. 2018. Hot-water extract of the branches of Hovenia dulcis Thunb. (Rahamnaceae) ameliorates low-fiber diet-induced constipation in rats. Drug Des. Devel. Ther. 3: 695-703.

33. Na JR, Oh KN, Park SU, Bae DH, Choi EJ, Jung MA, et al. 2013. The laxative effects of Maesil (Prunus mume Siebold \& Zucc.) on constipation induced by a low-fibre diet in a rat model. Int. J. Food Sci. Nutr. 64: 333-345.

34. Yang J, Ip PS, Yeung JH, Che CT. 2011. Inhibitory effect of schisandrin on spontaneous contraction of isolated rat colon. Phytomedicine 18: 998-1005.

35. Yang Z, Pan A, Zuo W, Guo J, Zhou W. 2014. Relaxant effect of flavonoid naringenin on contractile activity of rat colonic smooth muscle. J. Ethnopharmacol. 155: 1177-1183.

36. Kakino M, Tazawa S, Maruyama H, et al. 2010. Laxative effects of agarwood on low-fiber diet-induced constipation in rats. BMC Complement. Altern. Med. 10: 68.

37. Mostafa SM, Bhandari S, Ritchie G, Gratton N, Wenstone R. 2013. Constipation and its implications in the critically ill patient. Br. J. Anaesth. 91: 815-819.

38. Zhong LLD, Zheng G, Da Ge L, Lin CY, Huang T, Zhao L, et al. 2016. Chinese herbal medicine for constipation: zheng-based associations among herbs, formulae, proprietary medicines, and herb-drug interactions. Chin. Med. 11: 28.

39. Langmead L, Rampton DS. 2001. Review article: herbal treatment in gastrointestinal and liver disease--benefits and dangers. Aliment. Pharmacol. Ther. 15: 1239-1252.

40. Jang SH, Yang DK. 2018. The combination of Cassia obtusifolia L. and Foeniculum vulgare M. exhibits a laxative effect on loperamide-induced constipation of rats. PLoS One 13: e0195624.

41. Méité S, Bahi C, Yéo D, Datté JY, Djaman JA, N'guessan DJ. 2010. Laxative activities of Mareya micrantha (Benth.) Müll. Arg. (Euphorbiaceae) leaf aqueous extract in rats. BMC Complement. Altern. Med. 10: 7.

42. Wintola OA, Sunmonu TO, Afolayan AJ. 2010. The effect of Aloe ferox Mill. in the treatment of loperamide-induced constipation in Wistar rats. BMC Gastroenterol. 10: 95.

43. Makizaki Y, Maeda A, Oikawa Y, Tamura S, Tanaka Y, Nakajima S, et al. 2019. Alleviation of low-fiber diet-induced constipation by probiotic Bifidobacterium bifidum G9-1 is based on correction of gut microbiota dysbiosis. Biosci. Microbiota Food Health 38: 49-53.

44. Schemann M. 2005. Control of gastrointestinal motility by the "gut brain" - the enteric nervous system. J. Pediatr. Gastroenterol. Nutr. 41(Suppl 1): S4-S6.

45. Kim JE, Lee YJ, Kwak MH, Ko J, Hong JT, Hwang DY. 2013. Aqueous extracts of Liriope platyphylla induced significant laxative effects on loperamide-induced constipation of SD rats. BMC Complement. Altern. Med. 13: 333.

46. Pustovit RV, Furness JB, Rivera LR. 2015. A ghrelin receptor agonist is an effective colokinetic in rats with diet-induced constipation. Neurogastroenterol. Motil. 27: 610-617.

47. Zikos TA, Kamal AN, Neshatian L, Triadafilopoulos G, Clarke JO, Nandwani M, et al. 2019. High prevalence of slow transit constipation in patients with gastroparesis. J. Neurogastroenterol. Motil. 25: 267-275.

48. Portalatin M, Winstead N. 2002. Medical management of constipation. Clin. Colon Rectal. Surg. 25: 12-19.

49. Lecci A, Santicioli P, Maggi CA. 2002. Pharmacology of transmission to gastrointestinal muscle. Curr. Opin. Pharmacol. 2: 630-641.

50. Giaroni C, Knight GE, Ruan HZ, Glass R, Bardini M, Lecchini S, et al. 2002. P2 receptors in the murine gastrointestinal tract. Neuropharmacology 43: 1313-1323.

51. Giaroni C, Knight GE, Zanetti E, Chiaravalli AM, Lecchini S, Frigo G, et al. 2006. Postnatal development of P2 receptors in the murine gastrointestinal tract. Neuropharmacology 50: 690-704.

52. Serio R, Alessandro M, Zizzo MG, Tamburello MP, MulèF. 2003. Neurotransmitters involved in the fast inhibitory junction potentials in mouse distal colon. Eur. J. Pharmacol. 460: 183-190.

53. Mulé F, Naccari D, Serio R. 2005. Evidence for the presence of P2y and P2x receptors with different functions in mouse stomach. Eur. J. Pharmacol. 513: 135-140.

54. Zizzo MG, Mulè F, Serio R. 2007. Evidence that ATP or a related purine is an excitatory neurotransmitter in the longitudinal muscle of mouse distal colon. Br. J. Pharmacol. 151: 73-81.

55. Webb RC. 2003. Smooth muscle contraction and relaxation. Adv. Physiol. Educ. 27: 201-206.

56. Salter MW, Hicks JL. 1995. ATP causes release of intracellular $\mathrm{Ca}^{2+}$ via the phospholipase $\mathrm{C}$ beta/IP3 pathway in astrocytes from the dorsal spinal cord. J. Neurosci. 15: 2961-2971. 